\title{
INOVASI PELAYANAN RAPOR BERBASIS ONLINE DI SMA IPIEMS SURABAYA
}

\author{
${ }^{1}$ Hidayat Eko Novanto, ${ }^{2}$ Muhammad Arifin, ${ }^{3}$ Irfan Dwi Saputra, ${ }^{4}$ Diana Hertati \\ 1,2,3,4Administrasi Publik Fakultas IImu Sosial dan IImu Politik UPN "Veteran" Jawa Timur \\ dyatekoo@gmail.com, irfandwi37@gmail.com \\ Surabaya, Jawa Timur, Indonesia
}

\begin{abstract}
Online report card is a web-based value management system created by utilizing technology in its process to overcome the fundamental problems of processing and reporting grades in the 2013 Curriculum. Online report cards have been applied in various schools in the Surabaya area and currently the application has spread to various regions of Indonesia. In the application of online report cards there are various positive and negative impacts felt by the community. The research aims to analyze and see how the innovation of online report card services at IPIEMS Surabaya High School. The method used in this research is descriptive qualitative approach with data collection techniques using review literature. The focus in this research is based on Everett $M$ Rogers' theory of innovation attributes, namely relative advantage, suitability, complexity, probability, observability. The results of the analysis in the study using the attribute theory of online report card service innovation at IPIEMS Surabaya High School are in accordance and meet the 5 elements of innovation attributes by Everett M Rogers. Online report card service innovation implemented at SMA IPIEMS Surabaya can be carried out effectively and efficiently, besides that there is still a lack of relative benefits that do not cover the whole of online report card innovation.
\end{abstract}

Keywords: : Public Service; Online Report Card; 2013 Curriculum

\begin{abstract}
Abstrak
Rapor online merupakan sistem pengelolaan nilai berbasis web yang diciptakan dengan memanfaatkan ilmu teknologi dalam prosesnya untuk mengatasi permasalahan mendasar pengolahan dan pelaporan nilai pada Kurikulum 2013. Rapor online sudah diterapakan di seluruh sekolah yang ada di Surabaya dan saat ini penerapannya telah tersebar ke berbagai wilayah Indonesia. Dalam penerapan rapor online terdapat berbagai dampak positif dan negatif yang dirasakan oleh masyarakat. Penelitian ini bertujuan untuk menganalasis dan melihat bagaimana inovasi pelayanan rapor berbasis online di SMA IPIEMS Surabaya. Metode yang digunakan dalam penelitian yaitu metode deskriptif pendekatan kualitatif dengan teknik pengumpulan data menggunakan literatur riview. Fokus dalam penelitian ini yaitu keuntungan relatif, kesesuaian, kerumitan, kemungkinan coba, kemudahan diamati. Hasil dari analisis dalam penelitian menggunakan teori atribut inovasi pelayanan rapor berbasis online di SMA IPIEMS Surabaya telah sesuai dan memenuhi 5 elemen atribut inovasi oleh Everett $M$ Rogers. Inovasi pelayanan rapor berbasis online yang diterapkan di SMA IPIEMS Surabaya dapat terlaksana dengan efektif dan efesien, disamping itu masih terdapat kekurangan pada keuntungan relatif yang belum mencakup secara keseluruhan dari inovasi rapor online.
\end{abstract}

Kata Kunci: Kurikulum 2013; Pelayanan Publik; Rapor Online;

Received: DD/MM/YY; Revised: DD/MM/YY; Accepted: DD/MM/YY

Journal Publicuho is licensed under a Creative Commons Attribution 4.0 International License. 


\section{PENDAHULUAN}

Indonesia merupakan negara yang memiliki penduduk usia produktif lebih banyak daripada usia non-produktif. Banyaknya usia produktif maka akan mendapatkan keuntungan yang dapat dinikmati sebagai batu tanjakan dalam memajukan bangsa dan negara. Hal itu disebut dengan bonus demografi yang menjadi peluang indonesia untuk memajukan kesejahteraan serta kemakmuran masyarakat apabila usia produktif memiliki kualitas SDM yang baik dan dapat menunjang hingga memberikan kontribusi dalam pembangunan negara. Saat ini pemerintah Indonesia sedang gencar meningkatkan kualitas sumber daya manusia dengan melakukan peningkatan sistem pendidikan, salah satunya memperbaiki sarana dan prasarana dan tenaga pendidik, pemerataan kesempatan dalam mengenyam pendidikan serta pengembangan kurikulum sebagai dasar pemberian pendidikan yang mengacu Undang-Undang Republik Indonesia Nomor 20 Tahun 2003 Tentang Sistem Pendidikan Nasional strategi pada Bab XI pasal (35) Ayat 1. Standar nasional pendidikan digunakan sebagai dasar pengembangan kurikulum pembelajaran untuk mewujudkan tujuan nasional pendidikan. Perkembangan kurikulum pendidikan Indonesia dimulai pada tahun 1947,1964,1968,1973,1975,1984,199,2004,2006 dan 2013 yang saat ini dalam proses penerapan di seluruh wilayah Indonesia.

Kurikulum 2013 pengembangannya terletak pada keseimbangan antara pengetahuan, sikap dan keterampilan, model pembelajaran, serta penilaian autentik. Berdasarkan Peraturan Menteri Pendidikan Dan Kebudayaan Republik Indonesia Nomor 23 Tahun 2016 Tentang Standar Penilaian Pendidikan pasal (3) menjelaskan bahwa penilaian hasil belajar meliputi aspek sikap, pengetahuan dan keterampilan yang memiliki tujuan untuk memperoleh informasi secara deskriptif mengenai tingkah laku peserta didik pada saat proses pembelajaran, mengetahui tingkat pengetahuan serta penguasaan yang dimiliki oleh peserta didik, untuk mengukur penguasaan dan pengetahuan peserta didik dengan cara praktikum. Jika pengelolaan dan pelaporan nilai dilakukan secara manual maka membutuhkan waktu dan proses yang lama, membutuhkan konsentrasi tinggi, ketelitian, kedetailan dalam pengelolaan dan input data, jika tidak maka akan terjadi human error dalam pelaksanaan pengisian data nilai rapor Dengan itu diciptakan sebuah inovasi dalam pengelolaan dan pelaksanaan sistem penilaian dengan memanfaatkan teknologi informasi dan komunikasi dalam bentuk Rapor yang berbasis Web atau yang disebut rapor online.

Rapor online merupakan sistem pengelolaan nilai berbasis web yang diciptakan berdasarkan permasalahan yang ada di lapangan secara garis besar pada proses pembelajaran, tata cara pemberian dan pelaporan hasil penilaian, karena dalam kurikulum 2013 dituntut untuk memotret atau memberikan penilaian sebenar-benarnya pada peserta didik. Pemerintah Indonesia berusaha menerapkan sistem rapor online ini hingga keseluruh 
Journal Publicuho

ISSN 2621-1351 (online), ISSN 2685-0729 (print)

wilayah di Indonesia, termasuk kota Surabaya sebagai lbu Kota Provinsi Jawa Timur yang berusaha melakukan penerapan sistem rapor online tersebut kepada seluruh sekolah.

Tabel 1.

Jumlah Sekolah, Murid Dan Guru Kota Surabaya tahun 2017 dan 2018

\begin{tabular}{cccc}
\hline No & Keterangan & Tahun 2017 & Tahun 2018 \\
\hline 1 & Jumlah Sekolah & 168 & 133 \\
\hline 2 & Jumlah Murid & 68.614 & 60.235 \\
\hline 3 & Jumlah guru & 4.128 & 3.958 \\
\hline 4 & Rasio Murid dan Guru & 11.98 & 13.40 \\
\hline
\end{tabular}

Sumber : Badan Pusat Statistik Provinsi Jawa Timur, 2020

Pada tabel 1 dapat dilihat bahwa jumlah siswa lebih banyak daripada jumlah guru dan tenaga pendidik yang ada di kota surabaya. Jika penilaian manual tetap dilakukan maka tenaga pendidik atau guru akan di sibukan dengan administratif penilaian yang banyak. Hal tersebut sebagai pendorong Dinas Pendidikan Kota Surabaya menciptakan rapor online sehingga mampu meringankan kerja guru dalam melakukan penilaian kompleks pada kurikulum 2013, yang memuat penilaian kualitatif dan kuantitaif berdasarkan aspek penilaian pada Peraturan Kementrian Pendidikan dan Kebudayaan: Nomor 23 Tahun 2016 tentang Standar Penilaian Pendidikan pada pasal (3). Inovasi rapor online juga sebagai bentuk pelaksanaan E-Government yang mampu meberikan manfaat untuk Memperbaiki kualitas pelayanan pemerintah kepada para stakeholder, Meningkatkan kontrol, transparansi dan akuntabilitas terhadap penyelenggaraan pemerintah dalam bidang pendidikan seperti yang dijelaskan oleh Richardus Eko Indrajit dikutip dari (Indrajit, 2016:6)

Berdasarkan SK Kepala Dinas Pendidikan Kota Surabaya: Nomor 188/0978/436.6.4/2013 tentang Penerapan Sistem Rapor Online di Lingkungan Dinas Pendidikan Kota Surabaya tahun 2013, Surabaya melakukan penerapan rapor online dengan rancangan yang dapat diakses oleh orang tua siswa untuk menampilkan laporan hasil penilaian siswa, sehingga memberikan kemudahan bagi orang tua dalam memantau hasil pembelajaran serta berkomitmen dalam penerapan rapor online secara menyeluruh di sekolah yang ada di Surabaya. Namun dalam pelaksanaannya menghadapi kendala seperti minimnya pemahaman pemahaman TIK, server lemah, minim pemahaman tentang akses rapor melalui web oleh orang tua siswa model input/upload data pada web yang susah di pahami. Berdasarkan gambaran latar belakang tersebut, maka tujuan penelitian ini adalah untuk mengetahui inovasi pelayanan rapor berbasis online 


\section{METODOLOGI}

Dalam penelitian ini menggunakan metode deskriptif pendekatan kualitatif. Pengumpulan sumber data dilakukan dengan cara literatur review atau studi kepustakaan yang didapat melalui sumber seperti jurnal, buku dan artikel terdahulu untuk mendukung dalam penelitian karena pemahaman terhadap suatu permasalahan atau fenomena dapat dilakukan dengan cara mengenali serta membandingkan suatu hal dengan yang lain. Data yang diperoleh ditelaah, disusun secara sistematis, dibandingkan satu sama lain dan dibahas dengan literatur terkait (Fahmi, F. Y. \& Hidayati, 2016). teknik pengumpulan data dilakukan dengan tepat agar didapat data yang valid dan reliable. Lokus penelitian dilakukan di SMA Ipiem karena merupakan salah satu sekolah di Surabaya yang menrapkan rapor online. Fokus kajian dalam penelitian ini mengacu pada atribut inovasi yang dikemukakan oleh Everett $M$ Rogers meliputi keuntungan relatif, kompatibel (kesesuaian dengan nilai), kompleksitas (kerumitan), trialabilitas (kemungkinan dicoba), observabilitas (kemudahan diamati.

\section{HASIL DAN PEMBAHASAN}

berdasarkan budaya Indonesia yang beragam dan memiliki tujuan untuk mempersiapkan peserta didik demi melanjutkan hidupnya di masa depan dengan mempersiapkan Pendidikan yang mengutamakan aspek pengetahuan, keterampilan dan sikap demi terwujudnya sumber daya manusia yang berkualitas. Dalam perumusan hasil belajar pada Kurikulum 2013 harus secara autentik agar peserta didik mampu menggapai kompetensi yang diinginkan melalui hasil belajar. Jika perumusan hasil belajar di lakukan secara manual maka tidak akan efektif. Dari ketidakefektifan penggunaan rapor manual maka diciptakan sebuah inovasi Rapor online sebagai bentuk komitmen pelaksanaan Kurikulum 2013.

Rapor online merupakan sistem pengolahan nilai hasil belajar peserta didik yang berbasis Web atau online untuk mendukung implementasi Kurikulum 2013. Inovasi rapor online yang diciptakan oleh Surabaya melalui Dinas Pendidikan untuk mendukung kelancaran dan sebagai bentuk komitmen implementasi Kurikulum 2013 berdasarkan keluhan guru pada tahap evaluasi yang seperti disampaikan oleh Mendikbud Anies Baswedan karena penilaian kompetensi siswa tidak hanya menggunakan angka melainkan ditambahkan dengan variabel deskriptif, menjadi beban tambahan para guru, dan banyak guru yang tidak siap menjalankan, dikutip dari (Maharani, 2014)

Terciptanya inovasi rapor online juga berdasarkan aspek penilaian pada Kurikulum 2013 yang mengacu pada Permendikbud: Nomor 23 Tahun 2016 tentang Standar Penilaian Pendidikan yang pada pasal 3 menjelaskan bahwa penilaian hasil belajar meliputi aspek sikap, pengetahuan dan keterampilan yang harus dilakukan secara authentic assessment 
Journal Publicuho

ISSN 2621-1351 (online), ISSN 2685-0729 (print)

yaitu menggambarkan senyata-nyatanya hasil penilaian peserta didik. Penilaian dilakukan dengan kualitatif dan kuantitatif dimulai dari penilaian sikap, pengetahuan dan keterampilan sehingga dampaknya akan berkelanjutan. Jika penilaian dengan sistem manual terus dilakukan maka akibatnya guru akan disibukkan dengan urusan administrasi, sehingga inovasi tersebut dilakukan untuk mempermudah dan meringankan tugas guru terutama dalam aspek penilaian peserta didik.

Manfaat Inovasi rapor online secara garis besar mempermudah kerja guru dalam menyampaikan hasil evaluasi belajar siswa, sebagai back up data otomatis dan mempermudah pencarian apabila terjadi kehilangan seperti pada rapor manual, mempermudah guru dalam melakukan pengisian rapor, dan guru dapat mengerjakan tanpa adanya batasan ruang dan waktu. Dengan adanya penerapan rapor online pada lembaga pendidikan akan mempermudah guru serta lebih efektif dan efisien karena guru tidak perlu bekerja dua kali seperti penilaian yang ada di rapor manual, sehingga dapat meminimalisir human error dalam pengelolaan hasil penilaian belajar siswa.

Inovasi rapor online di SMA IPIEMS Surabaya berdasarkan artikel yang dikumpulkan dan dianalisis berdasarkan atribut inovasi menurut Everett M Rogers, yaitu:

\section{Keuntungan Relatif}

Inovasi program rapor online sebagai upaya Dinas Pendidikan Kota Surabaya untuk mendukung pelaksanaan Kurikulum 2013 sesuai mampu memberikan berbagai kemudahan dan sebagai alternatif pengolahan nilai hasil belajar siswa. Keuntungan utamanya dapat dirasakan oleh guru dan wali kelas sebagai tenaga pendidik yang bertugas untuk memberikan pelajaran dan hasil penilaian. Hasil penilaian yang diberikan mencakup aspek sikap, keterampilan dan pengetahuan secara individu dan berkelompok. Dikutip dari (Jatim, 2015) yang diakses pada tanggal 14 April 2020, menjelaskan bahwa 1 siswa setidaknya ada 472 kolom yang harus diisi. Apabila dilakukan secara manual, guru hanya menyetor ke wali kelas dan selanjutnya wali kelas yang harus menuliskannyaa dalam setiap rapor siswa terhitung 1 mata pelajaran, jika jenjang SMA terdapat 14 mata pelajaran maka wali kelas akan kerepotan dalam administrasi pengolahan nilai pada rapor, sehingga dengan adanya rapor online mampu mengurangi beban kerja guru dalam pengolahan dan penyampaian hasil belajar siswa.

Rapor online mampu memberikan rasa aman bagi pihak sekolah karena mampu mengurangi tingkat kecurangan dalam pengangkatan nilai siswa atau yang lebih sering disebut sebagai katrol nilai, sebagai backup data otomatis karena data akan terkunci jika dirasa sudah lengkap dalam rentang waktu 1 semester dan jika ada perubahan maka bisa 
hanya bisa diakses melalui Dindik. Selain itu dengan adanya rapor online mampu mengalokasikan sumber daya manusia seperti guru dan staf IT secara efektif dan maksimal dalam pengelolaan program rapor online sehingga kualitas, kuantitas serta pemahaman setiap guru terlihat dan dapat digunakan sebagai evaluasi jika terdapat kekurangan dan perbedaan pemahaman, dengan adanya evaluasi diharapkan mampu menyelaraskan tujuan dari adanya inovasi rapor online tersebut. Keuntungan juga dirasakan oleh wali murid yang dikutip dari (Roekminiati, Kamariyah, \& Astuti, 2016) menjelaskan dari hasil wawancara kepada salah satu wali murid bahwa memudahkan wali murid untuk melihat rapor tanpa adanya batasan ruang dan waktu. Rapor dapat di akses kapanpun, dimanapun menggunakan jaringan internet.

Namun fakta dilapangan masih banyak wali murid yang belum mengetahui rapor online. Dikutip dari (Hasan, 2014) menjelaskan bahwa diseminasi adalah suatu kegiatan yang ditujukan kepada kelompok, target atau individu agar mereka memperoleh informasi, sehingga timbul kesadaran, menerima dan akhirnya memanfaatkan informasi tersebut. Istilah umumnya adalah "penyebaran", maka kaitannya dengan inovasi rapor online, diseminasi dapat diartikan sebagai bentuk kegiatan penyebarluasan inovasi rapor online. Penyebaran informasi inovasi secara berkala sangat diperlukan agar kelompok sasaran yang dituju memiliki kesadaran untuk menerima inovasi sehingga mampu memanfaatkan secara optimal dan mampu mencapai tujuan diciptakannya inovasi. Hal itu selaras dengan kenyataan dilapangan bahwa masih banyak wali murid yang belum mengetahui inovasi rapor online. Minimnya sosialisasi dan penyebaran informasi menjadi penyebab utama adanya ketidaktahuan terhadap rapor online oleh wali murid. Selain itu, gagapnya pemahaman dunia digital oleh wali murid juga menjadi faktor yang menyebabkan ketidaktahuan.

\section{Kompatibel (kesesuaian)}

Dalam indikator ini dapat dilihat tingkat kesesuaian inovasi rapor online dalam mendukung implementasi Kurikulum 2013 untuk mencapai pelayanan pendidikan yang prima. Perencanaan inovasi program rapor online didasarkan atas permasalahan yang ada di lapangan dan secara garis besar meliputi tata cara pemberian dan pelaporan hasil penilaian pada Kurikulum 2013. Jika satu orang murid memiliki 472 kolom data dan harus dimasukkan dengan cara manual maka akan berat sehingga dengan adanya rapor online diharapkan tidak memberatkan tugas guru. Kesesuaian sasaran dan pelaksana inovasi dirasa sangat tepat karena ditujukan secara langsung untuk guru agar mempermudah dan membantu para guru dalam melakukan pengolahan serta pelaporan hasil penilaian seperti diungkapkan oleh Kepala Bidang Ketenagaan, Ir. Yusuf Masruh, MM yang dikutip dari 
Journal Publicuho

ISSN 2621-1351 (online), ISSN 2685-0729 (print)

(Hidayat, 2014). Output yang dihasilkan dari inovasi rapor online ini adalah memudahkan guru, peningkatan kinerja dan produktivitas guru.

Jika dilihat dari perspektif e-Government pada prinsipnya memberikan pelayanan dengan menggunakan teknologi komunikasi untuk meningkatkan kualitas dan proses pelayanan. Seperti yang diungkapkan oleh Richardus Eko Indrajit tentang manfaat dari eGovernment salah satunya adalah memberikan kualitas pelayanan pemerintah kepada para stakeholdernya (masyarakat, kalangan bisnis, dan industri) nterutama dalam hal kinerja efektivitas dan efisiensi di berbagai bidang kehidupan bernegara. Selaras dengan pernyataan tersebut, rapor online juga ditujukan untuk menciptakan transparansi, efektifitas dan efisiensi di bidang pendidikan khususnya dalam pengolahan dan pelaporan hasil penilaian belajar siswa sehingga menciptakan kepercayaan masyarakat terhadap pemberi layanan yaitu pihak sekolah yang mencakup staf, guru, kepala sekolah, pemerintah daerah dan pemerintah pusat.

\section{Kompleksitas (kerumitan)}

Dalam upaya memberikan kemudahan pengolahan, pelaporan serta akses hasil penilaian dan evaluasi belajar siswa akan mudah diterima. Ekspetasi kemunculan inovasi rapor online sangat modern dan memudahkan guru dalam proses pengolahan dan pelaporan penilaian hasil belajar siswa. Namun dalam pelaksanaannya sedikit terpatahkan. Dikutip dari (Ramli, 2020) yang menjelaskan bahwa proses pengisian nilai pada rapor online tidak semudah hanya memasukkan angka pada sebuah kolom penilaian. Jumlah kolom yang harus diisi pada setiap anak kurang lebih berjumlah 472, karena rapor online menggunakan sistem penilaian Kurikulum 2013 yang di setiap Kompetensi Dasar mempunyai nilai keterampilan, sikap dan pengetahuan sesuai dengan Permendikbud no 23 Tahun 2016 pasal 3. Sistem penilaian tersebut akan menjadikan data semakin banyak sehingga guru merasa kualahan dan bingung ketika mengolah nilai ke rapor online. selanjutnya permasalahan memasukkan nilai kedalam rapor online. Hal tersebut membutuhkan penanganan lebih karena terkait dengan persiapan sebelum memasukkan nilai dan melakukan sinkronisasi data rapor online dengan data Dapodik, selain itu juga membutuhkan komputer atau laptop yang berperan sebaga server yang tidak sepenuhnya guru memiliki akses tersebut.

Permasalahan server juga dikeluhkan karena sering tidak terhubung dengan Dapodik, hal tersebut dikarenakan pada saat instalasi aplikasi rapor online terjadi kesalahan dan aplikasi Dapodik versi lama. Pendapat berbeda diungkapkan oleh Supratman, S.Pd selaku Ka Kurikulum SMA Negeri 20 Surabaya yang dikutip dari (Roekminiati, Astuti, \& Kamariyah, 2018) dalam laporan penelitiannya menjelaskan bahwa tidak ada kendala berarti. Perbedaan tersebut terjadi karena pengalaman dan kebutuhan yang terlihat jelas 
antara guru yang berusia lanjut dan berusia muda. Ketersediaan sarana prasarana pendukung juga menjadi pengaruh terhadap kelancaran pelaksanaan inovasi rapor online seperti jaringan, akses internet maupun komputer. Staff IT yang dikhususkan untuk mengatasi segala permasalahan pada saat pelaksnaan tidak luput menjadi perhatian apabila pada saat itu ada beberapa guru yang mengalami permasalahan untuk meminta bantuan, sehingga guru tidak menunggu lama dan permasalahan yang dialami segera teratasi.

\section{Trialabilitas (kemungkinan dicoba)}

Dalam tahap uji coba sangat diperlukan adanya komunikasi kebijakan yang merupakan sebuah proses untuk penyampaian informasi kebijakan dari pembuat kebijakan kepada pelaksana kebijakan, dalam hal ini Dinas Pendidikan Kota Surabaya selaku pembuat kebijakan penerapan inovasi rapor online sebagai upaya percepatan penulisan rapor serta bertujuan untuk penyamaan pemikiran tentang penilaian siswa yang dilakukan secara terstruktur dan sistematis agar tujuan diciptakannya rapor online tercapai.

Inovasi rapor online diperlukan uji coba sebagai tahap awal pelaksanaan.

Kegiatan yang dilakukan untuk tahap uji coba adalah dengan mengadakan sosialisasi yang diselenggarakan oleh Dinas Pendidikan Kota Surabaya dengan Khoirul Anwar, Kepala SMA Negeri 7 Surabaya sebagai narasumber yang dikutip dari (Pemerintah Kota Surabaya, 2014) merupakan salah satu upaya dalam optimalisasi pengisian rapor online. Meskipun telah dilakukan sosialisasi dengan optimal oleh Dispendik ke seluruh sekolah namun masih ada perbedaan penerimaan informasi karena adanya perbedaan pemahaman dan perubahan pada sistem penulisan rapor menjadi online sehingga masih ada beberapa guru yang kesulitan dalam menggunakannya seperti yang disampaikan oleh (Firmanda \& Ma'ruf, 2017) dalam jurnalnya. Namun bimbingan teknis yang diberikan secara berkala dan berorientasi pada kemampuan sumber daya manusia untuk kinerja yang baik terus dilakukan sehingga mampu memberikan kontribusi dalam kesuksesan implementasi Kurikulum 2013 ataupun rapor online. Dengan adanya uji coba maka mampu mengukur tingkat efisiensi dan efektivitas, mampu melihat input dan output, Sehingga dapat diketahui inovasi rapor online tersebut berhasil atau gagal dan dapat digunakan sebagai masukan untuk proses pengambilan kebijakan pada masa yang akan datang.

\section{Observabilitas (kemudahan diamati)}

Inovasi rapor online merupakan bentuk peningkatan kualitas pelayanan yang diberikan oleh Dinas Pendidikan Kota Surabaya dan 1 langkah lebih maju memanfaatkan teknologi informasi dan komunikasi dalam pengolahan dan pelaporan hasil penilaian siswa. Dalam kemudahan untuk diamati dibuktikan dengan antusiasme setiap sekolah yang mendukung adanya penerapan inovasi rapor online. Penerapan dilakukan secara merata pada setiap sekolah yang ada di wilayah Indonesia, dari sekolah negeri maupun swasta. Kemudahan 


\section{Journal Publicuho}

ISSN 2621-1351 (online), ISSN 2685-0729 (print)

lainnya yang bisa diamati adalah rapor online bisa dikerjakan dimanapun dan kapanpun tanpa batasan ruang dan waktu, selain itu memasukkan nilai pada rapor online bisa dilakukan sedikit demi sedikit tanpa menunggu pertengahan semester maupun akhir semester.

\section{KESIMPULAN}

Berdsasarkan hasil analisa diatas dapat disimpulkan bahwa

1. Inovasi rapor online mampu memberikan keuntungan relatif yang mampu meringankan beban guru. Namun inovasi rapor online belum disosialisasikan secara merata kepada kelompok dan target tujuan yang lainnya yaitu wali murid sebagai pengguna dan penerima kebijakan inovasi rapor online tersebut.

2. Inovasi rapor online memiliki kesesuaian untuk mencapai pelayanan dalam bidang pendidikan yang prima.

3. Inovasi rapor online masih memiliki beberapa kerumitan baik saran pendukung maupun sumber daya manusia sebagai penerima dan pelaksana inovasi rapor online.

4. Inovasi rapor online sudah dilakukan uji coba dan disosialisasikan secara maksimal oleh Dinas Pendidikan Kota Surabaya keseluruh sekolah.

5. Inovasi rapor online memberikan kemudahan dalam pengolahan dan pelaporan nilai, sehingga dapat dikatakan bahwa kemudahan diamati pada inovasi rapor online mampu memberikan dampak positif bagi penerima dan pelaksananya meskipun inovasi rapor online belum diterima secara merata dalam hal ini adalah orang tua siswa atau wali murid.

\section{SARAN}

Pemerintah kota Surabaya perlu melakukan sosialisasi lebih jauh hingga menyentuh objek sasaran inovasi rapor online tersebut. Sehingga tujuan diciptakannya inovasi rapor online tersebut dapat tercapai dan diaplikasikan secara maksimal yang menjadi 1 langkah lebih maju pemanfaatan teknologi informasi komunikasi dalam dunia pendidikan. 


\section{DAFTAR PUSTAKA}

Akbar, M. F., \& Mohi, W. K. (2018). Studi Evaluasi Kebijakan (Evaluasi Beberapa Kebijakan Di Indonesia) (1st ed.; M. Mirnawati \& Y. Kamumu, Eds.). Gorontalo: Ideas Publishing.

Fahmi, F. Y., \& Hidayati, T. (2016). Gambaran Self Care Status Cairan Pada Pasien Hemodialisa ( Literatur Review ). Care: Jurnal Ilmiah Ilmu Kesehatan, 4(2), 53-63.

Firmanda, K. B., \& Ma'ruf, M. F. (2017). Implementasi Program Rapor Online Di SMK Negeri 1 Surabaya. Jurnal Ilmu Sosial Dan Hukum, 5(4), 1-8.

Gaufari, P. P. W., \& Eva, F. H. (2016). Manajemen Strategi Pengembangan Program Rapor Online Dinas Pendidikan Kota Surabaya Gaufari. Journal of Chemical Information and Modeling, 4(9), 1-10. https://doi.org/10.1017/CBO9781107415324.004

Hasan, A. (2014). Marketing dan Kasus-kasus Pilihan (Buku I, Ce). Yogyakarta: CAPS.

Hidayat, A. (2014). Permudah Akses Rapor Online, Dispendik Siapkan Layanan Khusus. Diambil tanggal 14 April 2020 dari Gurukita.com: http://www.gurukita.com/2014/12/permudah-akses-rapor-online-dispendik.html

Hiplundin, A. (2017). Kebijakan, Birokrasi, Dan Pelayanan Publik ( 1st ed.). Yogyakarta Calpulis Indrajit, R. E. (2016). Electronic Government. Yogyakarta: Preinexus.

Jatim, D. (2015). Program Rapor Online Permudah Tugas Guru dan Wali Kelas Isi Nilai Siswa. Retrieved April 14, 2020, from kominfo.jatimprov.go.id website: http://kominfo.jatimprov.go.id/read/umum/program-rapor-online-permudah-tugasguru-dan-wali-kelas-isi-nilai-siswa\#

Kadji, Y. (2015). Formulasi Dan Implementasi Kebijakan Publik Kepemimpinan dan Perilaku Birokrasi Dalam Fakta Realitas (1st ed.; I. Male, Ed.). Gorontalo: UNG Press Gorontalo.

Maharani, E. (2014). Rapor Online, Solusi K-13 Dari Surabaya. Retrieved April 14, 2020, from Republika.co.id website: https://nasional.republika.co.id/berita/nasional/umum/ng9vme/rapor-online-solusik13-dari-surabaya

Pemerintah Kota Surabaya. (2014). Optimalkan Pengisian Rapor Online, Dispendik Gelar Sosialisasi. Diambil tanggal 14 April 2020 dari Surabaya.go.id: https://surabaya.go.id/id/berita/2954/optimalkan-pengisian-rapor-online

Peraturan Menteri Pendidikan Dan Kebudayaan Republik Indonesia Nomor 23 Tahun 2016 Tentang Standar Penilaian Pendidikan.

Ramli, H. N. (2020). Problem Implementasi e-Rapor. Retrieved April 14, 2020, from akuratnews.com website: https://akuratnews.com/problem-implementasi-e-rapor/ Roekminiati, S., Astuti, C., \& Kamariyah, S. (2018). Evaluasi pelaksanaan E-Rapor Pasca Peralihan Pengelolaan Pemerintah Provinsi (studi kasus di SMA Negeri 19 dan SMA Negeri 20 Surabaya. Jurusan Administrasi Negara Fakultas IImu Administrasi Universitas Dr. Soetomo, Surabaya.

Roekminiati, S., Kamariyah, S., \& Astuti, C. (2016). Laporan Hasil Penelitian Dosen Program Studi Evaluasi Terhadap Pelayanan Rapor Online di SMP Negeri 12 Surabaya Tim Peneliti. Ilmu Sosial.

Rogers, E. M. (2003). Diffusion of Innovation (Free Press). New Yorks: A Division of Macmillan Publishing. 
Ros Indri Puji Saputro, W., \& Nurhikmahyanti, D. (2016). Pelaksanaan Rapor Online Pada Penilaian Hasil Belajar Kurikulum 2013 Di Smp Negeri 40 Surabaya. Jurnal Manajemen Pendidikan, 4(1), 1-8.

Sa'ud, U. S. (2014). Inovasi Pendidikan. Bandung: ALFABETA.

Sugiyono. (2008). Metode Penelitian Administrasi. Bandung: Alfabeta.

Surat Keputusan Menteri Pendayagunaan Aparatur Negara Nomor: 63/KEP/M.PAN/7/2003 tentang Pedoman Umum Penyelenggaraan Pelayanan Publik.

Taufiqurakhman. (2014). kebijakan Publik Pendelegasian Tanggungjawab Negara Kepada Presiden Selaku Penyelenggara Pemerintahan. Jakarta: Fakultas IImu Sosial dan IImu Politik Universitas Moestopo Beragama (Pers).

Undang-Undang Republik Indonesia Nomor 20 Tahun 2003 Tentang Sistem Pendidikan Nasional strategi.

Zahrotul, U. (2015). Social Strategy Pada Media Sosial Untuk Promosi Pariwisata Daerah Istimewa Yogyakarta. Jurnal Interaksi, 4(2), 195-201. https://doi.org/10.14710/interaksi,4,2,195-201 